\title{
Impact of Digital Shariah Banking Systems on Cash-Waqf amongst Muslim Millennials
}

\author{
Hafidhotul Amaliyah', Djoko Hartono2 \\ ${ }^{1}$ Universitas Airlangga, Indonesia \\ ${ }^{2}$ IAI Al-Khoziny Sidoarjo, Indonesia \\ Hafidhotul.amaliyah-2020@feb.unair.ac.id,djoko_hartono70@yahoo.co.id
}

\begin{abstract}
This study has two objectives, the first is to explore the variables that affect the intention to pay cash waqf online and the second is to investigate the moderating effect of experience on the variables that affect the intention to pay cash waqf online using mobile learning of Indonesian Islamic banks in Indonesia millennials in Surabaya. This study uses a quantitative approach, using a questionnaire survey on Muslim millennials in six big cities in Indonesia to collect the required data from the target group using purposive sampling method, and then the data is analyzed using the Structural Equation Modeling-analysis technique. Partial Least Square (PLS-SEM) with the help of SmartPLS. This study is one of the first studies to investigate the factors that influence online cash waqf donations among millennial Muslims in Surabaya using UTAUT theory.
\end{abstract}

Keywords

UTAUT; online cash waqf; digital sharia banking system

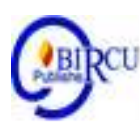

\section{Introduction}

A new disease that emerged in 2019 caused by the coronavirus has been designated by WHO as a pandemic in 2020. The disease caused by the corona virus or also known as covid19 of these are from Wuhan, China. result of the spread of COVID-19 is that it has claimed many human lives, and not only that, Covid-19 has also disrupted the economy throughout the world, one of which is Indonesia (Sri, 2021). In Indonesia, Covid-19 has caused many economic problems. As one of Islamic public finance, waqf can be used to help solve economic problems (Siska, 2021), one of which is to fulfill many services currently financed by the government, such as education, health care, food and shelter and transportation facilities (Mohsin, 2013). ). After the COVID-19 pandemic which began in early 2020, waqf has also been used to provide medical equipment and help those affected by the pandemic in several Muslim countries (Rahmatina, 2021). Sihombing (2020) state that Covid-19 pandemic caused everyone to behave beyond normal limits as usual. The outbreak of this virus has an impact especially on the economy of a nation and Globally (Ningrum, 2020). The problems posed by the Covid-19 pandemic which have become a global problem have the potential to trigger a new social order or reconstruction (Bara, 2021).

Although at the time of the Prophet Muhammad SAW, the scope of waqf was generally understood by the public to only include immovable assets such as mosques, tombs and other buildings and land. Thus, the mindset developed that waqf was only given by the rich and owners of land or buildings, but now the Islamic Fiqh Academy has emphasized that the scope of waqf can be expanded to include cash, services and benefits of new financial instruments such as shares and sukuk (Ahmed, 2019). Thus, cash waqf began to be used more widely in Muslim countries and communities. In recent years, cash waqf has been 
implemented in Malaysia, Turkey, Bangladesh and other Muslim countries (Hassan, 2019). It has also been practiced in Muslim communities in countries like Singapore as well as the UK. The context of waqf has also expanded in Indonesia. With the issuance of the Fatwa of the Indonesian Ulema Council (MUI) in 2002 and Law no. 41/2004 Concerning waqf, now Muslims in Indonesia can now donate in the form of movable goods such as money, securities and other movable objects. In addition, the law does not limit the amount of cash waqf that can be donated. In this case, the Indonesian Waqf Agency (BWI) has stated that cash waqf of at least IDR 10,000 can then be donated. In practice, some waqf organizations have encouraged and accepted cash waqf starting from IDR 5,000. This arrangement has contributed to the intensification of waqf in the form of cash in Indonesia. BWI estimates the potential for cash waqf is IDR 77 billion per year, but cash waqf income in Indonesia is in fact only around IDR 225 million in 2019 (KNKS, 2019).

There are various efforts made by Indonesian waqf bodies to increase the potential of waqf in Indonesia, namely by providing convenience in online cash waqf payments using digital Sharia banking in online cash waqf payments (Izra, 2021). This research was conducted on Muslim millennials who were born in vulnerable years 1981-1996 in Indonesia because of the dominance of the millennial population of around 25.95\% (BPS, 2020) and this generation understands and is actively using digital. To measure intentions to use digital Sharia banking in this study assessed using the UTAUT model because (Venkatesh, 2012) found that the important features of UTAUT had a considerable impact on behavioral intentions in their pioneering work. Performance expectations, effort expectations, social influences, and a favorable environment are all important factors of adoption and use behavior, according to a large number of UTAUT-related studies. Similarly, the characteristics of UTAUT have a significant impact on customers' usage intentions. The correlation between performance expectations and effort expectations and behavioral intentions has been documented in cross-cultural studies. In the case of cellular services, the anticipated effects of performance expectations and social influences on consumer behavioral intentions are also supported. All UTAUT anchors have a considerable effect on customer behavioral intentions, according to a recent attempt to re-examine the UTAUT paradigm (Dwivedi, 2016).

\section{Review of Literature}

\subsection{Online Cash Waqf}

Waqf is a type of voluntary charity that is included in the categories of alms (good deeds) and infaq (expenditures for the pleasure of Allah) (Ahmed, 2019). Waqf is one of the divine gifts recommended by Islam for the development of Muslims. The contribution of waqf is also encouraged by Islam, which encourages Muslims to donate a portion of their money to charitable causes. In addition, cash waqf is defined as charitable waqf established with cash capital. According to Mohsin (2009), it is "the retention of a sum of money from the founder and the dedication of its use forever for the benefit of the community. In addition there is also a wealth waqf which means as a continuous or temporary cash deposit to generate recurring benefits or benefits for general truth purposes. or privately according to the criteria set by the founders. The rules for cash waqf in Indonesia are regulated in the 2002 MUI Fatwa. According to the fatwa, cash waqf is waqf carried out in the form of money by a person, group, institution, or legal entity, with securities included in the definition It is also stated that the law on cash waqf is jawaz (permitted) as long as the funds are distributed and used for purposes that are in accordance with sharia. 
Furthermore, the main value of cash waqf must be guaranteed. Following the enactment of Law Number 41 of 2004 concerning Waqf, then the government issued Government Regulation No. 422006 which explicitly states that waqf of movable objects is included in cash waqf. (Tarsi, 2014) defines online waqf as "the notion of waqf management using the internet where transactions are handled online by accessing the waqf institution's website" in developing these concepts. In other words, online waqf refers to waqf transactions carried out online by anyone, anywhere. The availability of online waqf has made it easier for Muslims to donate as they can provide cash waqf instead of communicating privately with guardians, saving time and money.

\subsection{Digital Shariah Banking Systems}

The adoption of digital technology is an important issue to improve business performance and profitability of the banking industry (Wirdyanti, 2018). Digitization is the process by which organizations, businesses and the general public adopt digital or computer technology, including mobile applications. As a result, digital banking can be defined as the application of banking services that can be accessed through technology and information systems regardless of location or time. In fact, the wave of digital technology transformation has changed people's perceptions of how to communicate, do business, and conduct financial transactions, as well as bringing and shaping positive trends in the design of donation mechanisms and social activities that use digital payment transactions after partnering with Bank Muamalat Malaysia Berhad and utilizing payment methods. online in cash waqf participation, the number of cash waqf transactions has increased dramatically (Jalil, 2019).

\subsection{The UTAUT Model}

The UTAUT model is an integrated causal model that was developed to describe and predict the acceptance and use of technology in various fields and has been empirically tested for validity and reliability in several previous studies (James, 2021). In UTAUT theory, people's intention to pay cash waqf or BI behavior intention is influenced by several factors, namely Performance Expectancy, Effort Expectancy, Social Influence, Facilitating Conditions, Behavioral Intention. Performance Expectancy or what is called performance expectation is the extent to which a person believes that using the system will help him to achieve gains in his job performance. Performance expectations are a strong contraction of intention to use so that it can be concluded that someone who has believed an information system can help his work will tend to use the system for a longer time. In this concept there is a combination of variables obtained from previous research models regarding the acceptance and use of technology models (Ayad, 2021).

Behavioral intentions or individual intentions to perform a behavior are assumed to be motivational factors that will influence individual behavior, in the sense of showing how hard individuals try and the efforts they plan to do in carrying out a behavior (Rahmatina, 2021). Thus, the greater the individual's intention, the more likely the person is to perform a certain behavior. Intention is an individual's tendency to behave, until an attempt is made to move from the intention into the behavior itself. In this study, the concept of intention was used to predict the tendency of individuals to give cash waqf or donate through online waqf channels. Behavioral Intention (BI) assessment indicators are repurchase intentions where digital sharia mobile banking users want to reuse this application to pay cash waqf online. The second assessment is Positive word-of-mouth, where users talk about positive things about digital sharia mobile banking. And the last indicator, namely Service quality, means that the quality of technology services is very good for digital sharia mobile banking users.

The PE assessment indicator is according to (Venkatesh et al, 2012), namely perceived usefulness (PE), which is the level at which people believe that using digital sharia mobile 
banking will facilitate online cash waqf payments. Then the second job fit means that the use of digital sharia mobile banking helps solve my online cash waqf payment problem faster.

The second factor is Effort Expectancy (EE), which explains the extent to which a system or technology is easy to use. The assessment indicators according to (Venkatesh et al, 2012) are Perceived ease of use, which means that the digital sharia mobile banking system is easy to understand, then Complexity means that the digital sharia mobile banking system is difficult to understand and the last is Ease of use, which means that users are skilled in using digital. sharia mobile banking.

Then the third factor is Social Influence (SI) where this factor explains that someone uses technology because of encouragement from the people around them. The SI assessment indicator is the Subjective Norm, which means that the most important people in their lives influence the use of online cash waqf payments using the digital sharia mobile banking system. Then the second indicator is Social Factor, which means that a group or organization influences the use of online cash waqf payments using a digital sharia mobile banking system.

Furthermore, the fourth factor is Facilitating Conditions (FC). The assessment indicator of the FC variable is Perceived behavioral control, namely the assessment of resources owned, namely an internet connection to make online cash waqf payments using a digital sharia mobile banking system. Then the second assessment indicator is Facilitating conditions, namely an assessment of sharia bank services if there are problems when using the sharia digital mobile banking system.

\subsection{User Experience Moderator}

Mobile experience can be defined as a broad understanding of mobile telephony services such as mobile broadcasting, mobile purchasing, texting, mobile learning, and mobile gaming, rather than an in-depth understanding of a single mobile feature. Customers' confidence in their capacity to use and operate computers that help achieve their goals is expected to grow as the experience improves. Previous research has found that social influences (SI), performance expectations (PE), (FC), (EE) and (SA) have an important influence on intentions to use mobile learning, besides that there is a moderate variable that influences user experience (Ayad, 2021).

\subsection{Previous Research}

Some of the first Research conducted by Sok Foon \& Chan Yin Fah (2011) regarding internet banking adoption show that performance expectancy, effort expectancy, social influence and facilitating conditions and trust can explain $56.6 \%$ of respondents' behavior. In addition, the use of internet banking can reduce the frequency to the bank which indirectly reduces air pollution. Meanwhile, Pardamean \& Susanto (2012) in their research revealed that performance expectancy and social influence have a significant relationship to behavioral intention in students who apply learning tools using blogs in e-business.

Second, the next research conducted by Sulaeman and Ninglasari (2020) analyzes the factors that influence zakat receipts using the UTAUT model. The results of the study show that all variables except the facilitating condition have a significant positive effect on the intention to use a crowdfunding zakat-based

Third, research by Nuryahya et al., (2019) analyzes the factors that influence muzakki to accept and use platforms for online zakat payments by adopting the UTAUT model. The results show that performance expectancy has a high influence on the behavioral intentions of muzaki in receiving and using platform online zakat payment

The four studies by Wadi and Nurzaman (2020) aimed at knowing the determinants of millennials in the adoption of waqf technology using the UTAUT model. The results show 
that Performance Expectancy (PE), Effort Expectancy (EE), Social Influence (SI) are the main determinants of acceptance of waqf technology.

Fifth, the research conducted (Abdullah \& Bakri, 2021), the results of this study indicate that the intention of potential investors to donate money to a crowdfunding is influenced by performance performance expectancy, effort expectancy, and facilitating conditions that successfully contribute knowledge in the context of crowdfunding for the maintenance of public schools in Malaysia. .

\subsection{Hypothesis Development}

a. Relationship between PE and Intention to Pay Cash Waqf Online

In a study conducted by (Venkatesh, 2012) found a strong impact of the core elements of UTAUT on behavioral intentions. A significant body of research related to UTAUT has shown that the four anchors, namely, performance expectations, effort expectations, social influence and facilitation conditions are the main determinants of adoption and use behavior (see meta-analysis of (Khechine, 2016).This relationship has been supported in studies of travel-related behavior as well (Fong, 2017). Then the study observed the significant influence of UTAUT factors on consumer usage intentions.Cross-cultural studies documented the relationship of performance expectations and business expectations with behavioral intentions (Udo,2016). The proposed effect of performance expectations and influence Social influence on consumer behavioral intentions is also supported in the context of cellular services (Baishya, 2019).In a recent attempt to revisit the UTAUT framework, all UTAUT anchors exert a significant effect on consumer behavioral intentions (Dwivedi, 2019) thus hypothesized as follows:

H1 : Performance Expectancy is positively related to Intention Behavior

$\mathrm{H} 2$ : Effort Expectancy is positively related to Intention Behavior

H3: Social Influence is positively related to Intention Behavior

H4: Facilitating Conditions is positively related to Intention Behavior

\section{b. The Research Framework}

Following is the research framework of this study:

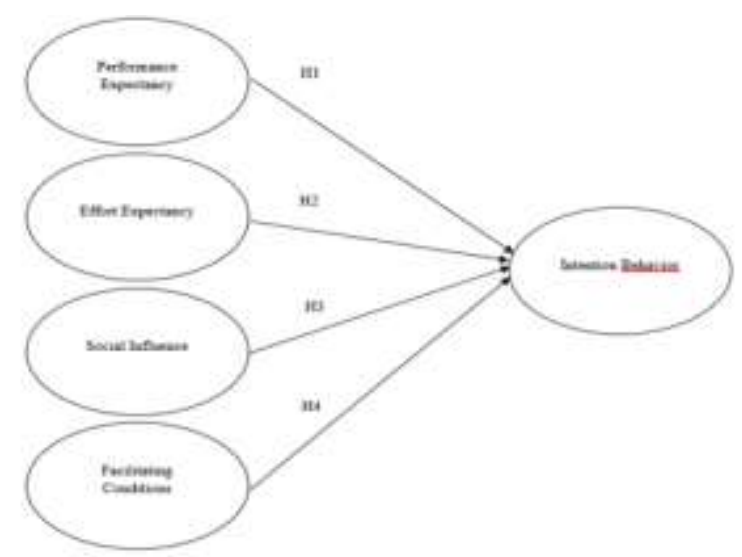

Figure 1. Research Framework

Source: Processed by the Author (2021) 


\section{Research Methods}

\subsection{Research Approach}

This study uses an approach quantitatively, using a questionnaire survey on 158 Muslim millennials in the city of Surabaya who use mobile banking of Indonesian Islamic banks to pay cash waqf online, then to collect the required data from the target group using the convenience sampling, and then the data is analyzed using the Structural Equation analysis technique. Modeling-Partial Least Square (PLS-SEM) with the help of SmartPLS.

\subsection{The Population and Sample Determination}

A unit of analysis in this study is waqf donors who pay waqf using mobile banking BSI in the Surabaya area. Questionnaires will be distributed and distributed in a period of 2 weeks with a cross sectional or one shot, ie data collected once. This method is expected to meet the requirements of random sampling.

\subsection{The Data Collection}

The object of this research is limited to waqf donors who pay waqf using BSI mobile banking. Due to the consideration of limited time, facilities, and research costs. The scope of this research is limited to the relationship: Performance Expectancy, Effort Expectancy, Social Influence, Facilitating conditions on Behavioral Intention.

\subsection{Phase Measurement Model (Outer Model)} a. Validity Test Validity

The test is used to determine the level of indicator ability to form latent variables (Sarjono and Julianita, 2015). In the convergent validity test, the outer loading value must be $>0.7$ and the average variance extracted (AVE) value $>0.5$, in the discriminant validity test, the cross loading each indicator must be > 0.7 (Abdillan and Jogiyanto, 2015).

\section{b. Reliability Test}

In this section, the reliability test is used to determine the consistency and accuracy of a model in making measurements. If the composite reliability $>0.7$ and Cronbach's alpha is $>0.6$, it is said to be reliable (Abdillah and Jogiyanto, 2015).

\section{c. Structural Model Measurement Phase (Inner Model)}

The structural model is evaluated using the R2 for the mediating variable and the dependent variable, the significance test between variables is tested by looking at the $\mathrm{t}$ statistic (Abdillah and Jogiyanto, 2015). The value of R2is used to measure the level of variance of changes in the independent variable to the dependent variable, the higher the value of R2,the better the predictive model of the study. The t-statistic $>1.96$ on the path coefficients between variables, shows a significant relationship (Abdillah and Jogiyanto, 2015).

\section{d. Data Analysis Techniques Data}

Analysis techniques in this study used the Structural Equation Model (SEM) technique with mediating effects using Smart Partial Least Squares (PLS). Smart PLS is a structure which assesses the reliability and validity of measures of theoretical constructs and estimates the relationship between constructs simultaneously (Thakur, 2014). This analytical technique is a combination of two methodological disciplines, namely the econometric perspective which focuses on predictions and psychometrics which is able to describe the concept of a model with latent variables (variables that are not measured 
directly) but through indicators (manifest variables). SEM essentially offers the ability to perform path analysis with latent variables (Ghozali and Latan, 2015). The steps for making modeling with PLS are; constructing path diagrams, designing measurement models (outer model), designing structural models (inner model), estimation (path coefficient, loading factor, and weight factor), R-square evaluation (Stone Geisser test), and hypothesis testing.

\section{e. Descriptive Statistical Test Descriptive}

Analysis is used to explain and inform the characteristics of respondents and descriptions of variables. Descriptive statistical research aims to describe the state of social phenomena as they are, without looking at existing relationships (Bungin, 2013). Descriptive statistical tests will be carried out by processing the data from the questionnaire by grouping and tabulating then it will be explained.

\section{f. Hypothesis}

Testing is a procedure based on sample evidence and probability theory to determine whether a hypothesis is correct (Lind et al, 2014). Hypothesis testing was carried out using the Structural Equation Model (SEM) approach using Partial Least Square (PLS) software version 3.0. SEM is one type of multivariate analysis in the social sciences. Multivariate analysis is the application of statistical methods for simultaneous analysis of several research variables (Sholihin and Ratmono, 2013).

\subsection{Operational Definition}

1) Performance Expectancy (PE) is a variable in the UTAUT model which is defined as a reference to the extent to which an individual feels that using the system will help him achieve profits and job performance.

2) Effort Expectancy (EE) is a variable in the UTAUT model which is defined as the level of ease associated with using a system.

3) Social Influence (SI) variable in the UTAUT model which is defined as the individual feels the importance that other people believe he should use the new system.

4) Behavioral Intention (BI) is a variable in the UTAUT model which is defined as a reference to the motivational factors that influence the behavior where the stronger the intention to perform the behavior, the more likely the behavior will be carried out.

5) Facilitating Conditions (FC) is a variable that has a direct influence on the use of the system and is also defined as "the extent to which a person believes that the organizational and technical infrastructure can support the use of the system.

\section{Discussion}

\subsection{Results}

\section{a. Description of Respondents}

This section describes the results of research and data analysis that has been collected through the distribution of online (Google Form) which the researchers conducted for two weeks in November 2021. Researchers will analyze the data that has been collected according to the main problems described at the beginning of the chapter. . The results of data processing are information that will later indicate whether the formulated hypothesis can be accepted or not.

\section{b. Age of Respondents}

The results of the analysis of respondents' characteristics by gender can be shown in Figure 1: 


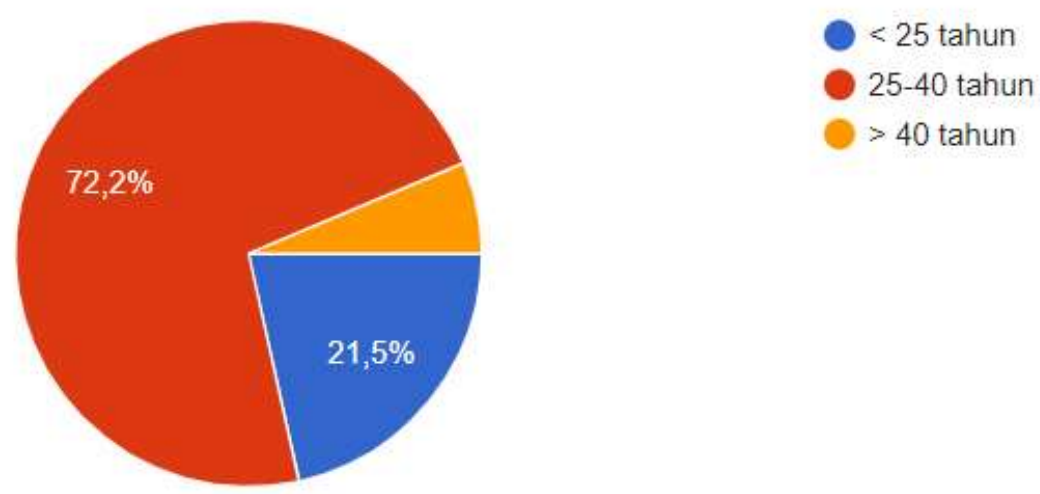

Figure 2. Respondents' Age Data (in percent)

Source: Google Form Questionnaire Results, 2021

Based on Figure 1 it can be seen that respondents are divided into three categories, namely respondents aged $<25$ years, respondents aged 25-40, and respondents aged $>40$ years. From the data obtained from 158 respondents, the composition of respondents based on age is 114 respondents or $72.2 \%$ aged $25-40$ years and 34 respondents aged 25 years or $21.5 \%$ then 10 respondents or $6.3 \%$ aged $>40$ years as shown in Figure 1 .

\section{c. BSI Users}

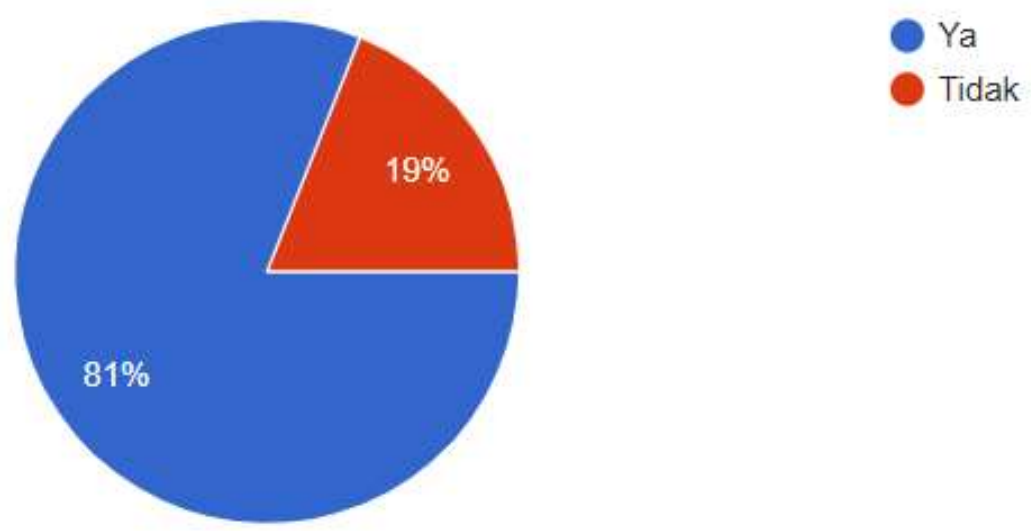

Figure 3. Respondent Data Based on BSI Users (in percent)

Source: Google Questionnaire Result Form, 2021

Based on Figure 2. It can be seen that respondents are divided into two, namely respondents who are BSI mobile banking users or not BSI mobile banking users. From the data obtained from 158 respondents, the composition of respondents based on BSI mobile banking users is 128 respondents or as many as $81 \%$ use BSI mobile banking and 30 respondents or $19 \%$ do not use BSI mobile banking, as shown in Figure 2.

\section{d. Convergent Validity Test Convergent}

Validity is the extent to which measure is positively correlated with alternative measures of the same construct. To evaluate the convergent validity of the reflective construct, the researcher considers the outer loadings indicator and average variance extracted (AVE). The high outer loadings on the construct show the related indicators have a lot in common, which is captured by the construct. At a minimum, the outer loadings of all 
indicators should be statistically significant. A general rule of thumb is that the default outer loading should be 0.7 or higher. The following are the results of the Convergent Test:

Table 1. The Results of Convergent Test

\begin{tabular}{|c|c|c|c|c|c|}
\hline & $\mathrm{Xl}$ & $\mathrm{X} 2$ & $\mathrm{X} 3$ & $\mathrm{X} 4$ & Y1 \\
\hline X1.1 & 0,816 & & & & \\
\hline X1.2 & 0,763 & & & & \\
\hline X1.4 & 0,824 & & & & \\
\hline $\mathrm{X} 2.1$ & & 0,815 & & & \\
\hline $\mathrm{X} 2.2$ & & 0,811 & & & \\
\hline $\mathrm{X} 2.3$ & & 0,775 & & & \\
\hline $\mathrm{X} 3.1$ & & & 0,902 & & \\
\hline $\mathrm{X} 3.2$ & & & 0,926 & & \\
\hline X4.1 & & & & 0,789 & \\
\hline $\mathrm{X} 4.2$ & & & & 0,879 & \\
\hline $\mathrm{X} 4.3$ & & & & 0,708 & \\
\hline Y1.1 & & & & & 0,878 \\
\hline Y1.2 & & & & & 0,870 \\
\hline Y1.3 & & & & & 0,859 \\
\hline
\end{tabular}

\section{e. Discriminant Validity Test Discriminant}

Validity is the extent to which a construct is completely different from another construct by empirical standards. Thus, determining discriminant validity implies that a construct is unique and captures phenomena that are not represented by other constructs in the model. Traditionally, researchers have relied on two measures of discriminant validity. Cross-loadings are usually the first approach to assessing the discriminant validity of an indicator. In particular, the outer loadings indicator on the associated construct must be greater than any cross-loadings (i.e., the correlation) on the other constructs. The following are the results of the Discriminant Validity Test

Table 2. The Results of Discriminant Validity Test

\begin{tabular}{|c|c|c|c|c|}
\hline & Cronbach's Alpha & rhooeat & $\begin{array}{l}\text { Composite } \\
\text { Reliability }\end{array}$ & $\begin{array}{l}\text { Average Variance Extracted } \\
\text { (AVE) }\end{array}$ \\
\hline Xl & 0,723 & 0,731 & 0,844 & 0,643 \\
\hline $\mathrm{X} 2$ & 0,720 & 0,719 & 0,842 & 0,641 \\
\hline $\mathbf{X 3}$ & 0,803 & 0,813 & 0,910 & 0,835 \\
\hline $\mathrm{X} 4$ & 0,708 & 0,749 & 0,836 & 0,632 \\
\hline Y1 & $0, \mathbf{8 3 8}$ & 0,844 & 0,902 & 0,755 \\
\hline
\end{tabular}

\section{f. Reliability Test}

The reliability test was carried out to prove the accuracy of the consistency and accuracy of the instrument in measuring constructs, reliability was assessed based on the Composite Reliability value and Cronbach's alpha value, the Rule of thumb used for Composite Reliability values greater than 0.7 and Cronbach's alpha value greater than 0.7 (Ghozali and Latan, 2015: 75). Here are the results of the reliability test: 
Table 3. The Results of Realibility Test

\begin{tabular}{|l|r|r|r|rr|}
\hline & $\begin{array}{c}\text { Cronbach's } \\
\text { Alpha }\end{array}$ & rhooeA & $\begin{array}{c}\text { Composite } \\
\text { Reliability }\end{array}$ & $\begin{array}{c}\text { Average Variance Extracted } \\
\text { (AVE) }\end{array}$ \\
\hline X1 & 0,723 & 0,731 & 0,844 & 0,643 \\
\hline X2 & 0,720 & 0,719 & 0,842 & 0,641 \\
\hline X3 & 0,803 & 0,813 & 0,910 & 0,835 \\
\hline X4 & 0,708 & 0,749 & 0,836 & 0,632 \\
\hline Y1 & 0,838 & 0,844 & 0,902 & 0,755 \\
\hline
\end{tabular}

\section{g. Goodness of Fit Model PLS}

At this stage, testing will be carried out on the suitability of the model through various goodness-of-fit criteria. Partial Least Square (PLS) does not assume a certain distribution for parameter estimation so that parametric techniques to test the significance of parameters are not needed. The measurement model or outer model with reflexive indicators is evaluated with convergent and discriminant validity of the indicators and composite reliability for indicator blocks. While the outer model with formative indicators is evaluated based on its substantive content, namely by comparing the relative weight and seeing the significance of the weight size (Solimun, 2008). Following are the results of Goodness of Fit:

Table 4. Testing Structural Equation Model (SEM)

\begin{tabular}{|l|r|r|}
\hline & \multicolumn{1}{|c|}{$\begin{array}{c}\text { Saturated } \\
\text { Model }\end{array}$} & \multicolumn{1}{c|}{$\begin{array}{c}\text { Estimated } \\
\text { Model }\end{array}$} \\
\hline SRMR & 0,082 & 0,082 \\
\hline do.ULS & 0,706 & 0,706 \\
\hline d.G & 0,346 & 0,346 \\
\hline Chi-Square & 301,259 & 301,259 \\
\hline NFI & 0,701 & 0,701 \\
\hline
\end{tabular}

Research hypotheses were carried out using the Structural Equation Model (SEM) approach based on Partial Least Square (PLS). PLS is a component or variance based structural equation model (SEM). Structural Equation Model (SEM) is a field of statistical study that can test a series of relationships that are relatively difficult to measure simultaneously. According to Santoso (2014) SEM is a multivariate analysis technique which is a combination of factor analysis and regression analysis (correlation), which aims to examine the relationship between variables that exist in a model, both between indicators and their constructs, or relationships between constructs. Following is the PLS SEM Model:

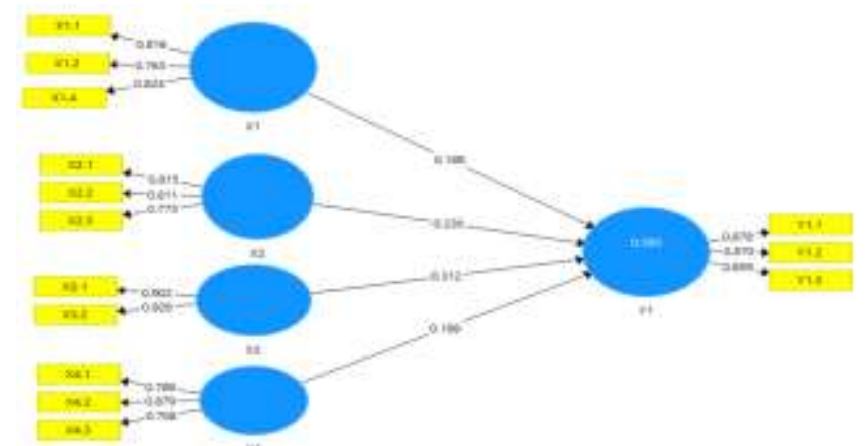

Figure 4. The PLS SEM Model 


\section{h. Relationship of Variables}

With SEM, marketers can visually examine the relationships that exist among the variables of interest to prioritize resources to better serve their customers. The fact that difficult to observe and measurable latent variables can be used in SEM makes it ideal for tackling business research problems.

There are two sub models in the structural equation model, namely the model in determining the relationship between independent and dependent latent variables, while the outer model determines the relationship between latent variables and their observed indicators. In SEM, variables can be exogenous or endogenous, exogenous variables have pathways that lead outward and none that lead to them. Meanwhile, endogenous variables have at least one path to get there and represent the effects of other variables. Here are the results of the variable relationship:

Table 5. The Results of Variable Relationship

\begin{tabular}{|c|c|c|c|c|c|}
\hline & $\begin{array}{c}\text { Original } \\
\text { Sample } \\
(0)\end{array}$ & $\begin{array}{l}\text { Sample Mean } \\
\text { (M) }\end{array}$ & $\begin{array}{l}\text { Standard } \\
\text { Deviation } \\
\text { (STDEV) }\end{array}$ & $\begin{array}{l}\text { T Statistics } \\
(\mid \mathbf{O} / \text { STDEV } \mid)\end{array}$ & $P$ Values \\
\hline $\mathrm{Xl} \rightarrow \mathrm{Yl}$ & 0,189 & 0,184 & 0,071 & 2,658 & 0,008 \\
\hline $\mathrm{X} 2 \rightarrow \mathrm{Y} 1$ & 0,230 & 0,229 & 0,087 & 2,645 & 0,008 \\
\hline $\mathrm{X} 3 \rightarrow \mathrm{Yl}$ & 0,312 & 0,306 & 0,083 & 3,748 & 0,000 \\
\hline $\mathrm{X} 4->\mathrm{Yl}$ & 0,198 & 0,209 & 0,104 & 1,916 & 0,056 \\
\hline
\end{tabular}

\section{i. Path Coefficient Test Path Coefficient}

Path Coefficient Test Path is evaluation used to show how strong the effect or influence of the independent variable on the dependent variable. While the coefficient determination ( $R$-Square) is used to measure how much the endogenous variable is influenced by other variables. Chin said the results of $\mathrm{R} 2^{\text {and }}$ above for endogenous latent variables in the structural model indicated that the effect of exogenous variables (influenced) on endogenous variables (influenced) was in the good category. Meanwhile, if the result is $0.33-0.67$ then it is included in the medium category, and if the result is $0.19-$ 0.33 then it is included in the weak category. The following are the results of the relationship between variables:

Table 6. The Results of Relationship between Variables

\begin{tabular}{|l|r|r|r|r|r|}
\hline & $\begin{array}{l}\text { Original } \\
\text { Sample } \\
\text { (O) }\end{array}$ & Sample Mean (M) & $\begin{array}{l}\text { Standard } \\
\text { Deviation } \\
\text { (STDEV) }\end{array}$ & $\begin{array}{l}\text { T Statistics } \\
\text { (|O/STDEV|) }\end{array}$ & $\begin{array}{l}\text { P } \\
\text { Values }\end{array}$ \\
\hline $\mathrm{X} 1>\mathrm{Y} 1$ & 0,189 & 0,181 & 0,075 & 2,509 & 0,012 \\
\hline $\mathrm{X} 2 \rightarrow \mathrm{Y} 1$ & 0,230 & 0,233 & 0,083 & 2,769 & 0,006 \\
\hline $\mathrm{X} 3 \rightarrow \mathrm{Y} 1$ & 0,312 & 0,299 & 0,091 & 3,438 & 0,001 \\
\hline $\mathrm{X} 4 \rightarrow \mathrm{Y} 1$ & 0,198 & 0,215 & 0,109 & 1,822 & 0,069 \\
\hline
\end{tabular}

\subsection{Discussion}

The purpose of this study is supported by the results of research showing a good measurement model. In this study consisting of 4 (four) hypotheses, the results show a good measurement model where 4 (four) hypotheses from this study support that the behavioral intention of donors (wakif) in using BSI mobile banking is influenced by Performance Expectancy, Effort Expectancy, Social Influence, and Facilitating Conditions. 


\section{a. Effect Performance Expectancy Muslim Millennials Behavior Intention Using Mobile}

Banking BSI

From the results of testing the second hypothesis, it can be concluded that the variable Performance Expectancy has a positive effect on Behavioral Intention using mobile banking BSI. Path analysis between Performance Expectancy and wakif behavioral intention based on the research results is significant and positive. The results of this study are in line with research conducted by James (2021), Sulaiman \& Ninglasari (2020), Diniyah (2021), and Zainab (2018) which explains that Performance Expectancy has a positive effect on Behavioral Intention. This is because waqf donors are more confident and comfortable making cash waqf payments online using BSI mobile banking rather than having to go to a ziswaf institution.

\section{b. Effect Effort Expectancy Muslim Millennials Behavioral Intention Using BSI Mobile Banking}

From the results of testing the second hypothesis, it can be concluded that the Effort Expectancy has a positive effect on Behavioral Intention using BSI mobile banking. Path analysis between Effort Expectancy and behavioral intentions of waqf donors based on research results is significant and positive. The results of this study are in line with research conducted by Diniyah (2021), Fedorko et al. (2021), Sulaiman \& Ninglasari (2020) who explained that Effort Expectancy had a positive effect on Behavioral Intention. This is due to the convenience of using BSI mobile banking in paying cash waqf online which can save the time and energy of donors or what is known as waqif compared to visiting the ziswaf unit or institution directly.

\section{c. The Effect Social Influence Muslim Millennials Behavior Intention Using Mobile Banking BSI}

From the results of testing the second hypothesis, it can be concluded that the Social Influence has a positive effect on Behavioral Intention use mobile banking BSI. Path analysis between Social Influence and wakif behavioral intention based on the research results is significant and positive. Thus, the results of this study are in line with research conducted by Diniyah (2021), Bakri et al. (2021), Sulaiman \& Ninglasari (2020), who explained that Social Influence had a positive effect on Behavioral Intention. This is because the behavioral intentions of waqf donors are influenced by trust, environment and technological developments owned by the donors, namely smartphones with internet access, making it easy for waqf donors to use mobile banking BSI.

\section{d. Effect Facilitating Conditions Muslim Millennials Behavioral Intention Using Mobile Banking BSI}

From the results of testing the second hypothesis, it can be concluded that the variable Facilitating Conditions has a positive effect on Behavioral Intention using mobile banking BSI. Path analysis between Social Influence and wakif behavioral intention based on the research results is negative. This is because donors have difficulty in waqf using BSI mobile banking. This can be caused because even though the donor has a smartphone, the donors do not understand the system on their respective smartphones, this causes the donors to have difficulty in waqf using BSI mobile banking. So the results of this study are in line with research conducted by Yang et al. (2021), who found that FC did not significantly influence consumers' intention to use digital payment solutions as their preferred payment method based on their analysis. 


\section{Conclusion}

Based on the results of the research conducted, it shows that the Performance Expectancy, Effort Expectancy, Social Influence have a positive effect on Muslim millennials behavioral intention to use BSI mobile banking, because the services provided by Indonesian Islamic banks, namely the BSI mobile banking provide convenience for waqf donors in carrying out theironline cash waqf payments, especially during the COVID-19 pandemic, which requires donors to reduce the intensity of meeting other people in order to cut the chain of spreading the COVID-19 virus. Meanwhile, the Facilitating Conditions has a negative effect on Muslim millennials behavioral intention to use BSI mobile banking, this is due to the lack of system convenience and the lack of CS assistance in assisting waqf donors in making online cash waqf payments using BSI mobile banking. So it is necessary to increase the ease of CS complaints if there are problems in online cash waqf payments on BSI mobile banking.

\section{References}

Ahmed, H. (2019), "Legal constraints to the development of waqf", In Revitalization of Waqf for SocioEconomic Development, Palgrave Macmillan, Cham, Vol. 2, pp. 153-174.

Ayad Shihan Izkair. (2021). Experience moderator effect on the variables that influence intention to use mobile learning. Bulletin of Electrical Engineering and Informatics. Vol. 10, No. 5, October 2021, pp. 2875 2883.

Baishya, K., Samalia, HV, 2020. Memperluas teori penerimaan dan penggunaan terpadu teknologi dengan nilai moneter yang dirasakan untuk adopsi smartphone di bagian bawah piramida. Int. J.Inf. Kelola. 51, 102036.

Bakri, M. H., Md Radzai, M. S., \& Rasid, A. M. M. (2021). Technology acceptance in crowdfunding among retailers. Estudios de Economia Aplicada, 39(5), 1-12.

Bara, A., et.al. (2021). The Effectiveness of Advertising Marketing in Print Media during the Covid 19 Pandemic in the Mandailing Natal Region. Budapest International Research and Critics Institute-Journal (BIRCI-Journal) Vol 4 (1): 879-886.

Diniyah, F. (2021). Faktor yang Mempengaruhi Niat Perilaku Muslim Menggunakan Platform Crowdfunding Waqf: Teori UTAUT Model. Jurnal Ilmiah Ekonomi Islam, 7(2), 544-552. https://doi.org/10.29040/jiei.v7i2.1841.

Dwivedi, Y.K., Shareef, M.A., Simintiras, A.C., Lal, B., Weerakkody, V., 2016. A generalised adoption model for services: a cross-country comparison of mobile health (m-health). Govern. Inf. Q. 33 (1), 174-187.

Fedorko, I., Bacik, R., \& Gavurova, B. (2021). Effort expectancy and social influence factors as main determinants of performance expectancy using electronic banking. Banks and Bank Systems, 16(2), 27-37.

Fong, LHN, Lam, LW, Law, R., 2017. Bagaimana locus of control membentuk niat untuk menggunakan kembali aplikasi seluler untuk membuat reservasi hotel: bukti dari konsumen Cina. Manajer Pariwisata. 61,331-342.

Hasan, R., Hassan, M.K. and Rashid, M. (2019), "Mediating role of trust in cash waqf donations", in Ali, K., Hassan, M. and Ali, A. (Eds), Revitalization of Waqf for SocioEconomic Development, Volume II, Palgrave Macmillan, Cham.

Https://www.bps.go.id. Diakses 1 November 2021

Izra Berakon. (2021). Impact of digital Sharia banking systems on cash-waqf among Indonesian Muslim youth. Journal of Islamic Marketing. 1759-0833. 
Jalil, M.I.A., Pitchay, A.A. and Yahya, S. (2019), "Cash waqf and preferred method of payment: case of Malaysia using an AHP approach", Revitalization of Waqf for SocioEconomic Development, Vol. 2, doi: 10.1007/978-3-030-18449-0.

James E. (2021). UTAUT as a Model for Understanding Intention to Adopt AI and Related Technologies among Librarians. The Journal of Academic Librarianship. 47 (2021) 102437.

Khechine, H., Lakhal, S., Ndjambou, P., 2016. Sebuah meta-analisis dari model UTAUT: sebelas tahun kemudian. Bisa. J.Adm.Sci. Pdt. Kanada. Sci. Adm.33 (2), 138-152.

KNKS (2019), "Optimalisasi wakaf produktif untuk kesejahteraan ummat", INSIGHT (Buletin Ekonomi Syariah), Jakarta: September 2019.

Mohsin, MIA (2013), "Pembiayaan melalui wakaf tunai: revitalisasi untuk membiayai kebutuhan yang berbeda", Jurnal Internasional Keuangan dan Manajemen Islam dan Timur Tengah, Jil. 6 No.4, hal.304-321.

Ningrum, P.A., Hukom, A., and Adiwijaya, S. (2020). The Potential of Poverty in the City of Palangka Raya: Study SMIs Affected Pandemic Covid 19. Budapest International Research and Critics Institute-Journal (BIRCI-Journal) Vol 3 (3): 1626-1634.

Rahmatina. (2020). The role of knowledge, trust, and religiosity in explaining the online cash waqf amongst Muslim millennials. Journal of Islamic Marketing. 1759-0833.

Sihombing, E.H., and Nasib. (2020). The Decision of Choosing Course in the Era of Covid 19 through the Telemarketing Program, Personal Selling and College Image. Budapest International Research and Critics Institute-Journal (BIRCI-Journal) Vol 3 (4): 28432850 .

Siska L. (2021). Aspek Hukum Peran Wakaf Tunai Pada Masa Pandemi Covid 19. Jurnal Hukum \& Pembangunan 51 No. 1 (2021): 217-228.

Sulaeman, S., \& Ninglasari, S. Y. (2020). An Empirical Examination of Factors Influencing the Behavioral Intention to Use Zakat-Based Crowdfunding Platform Model for Countering the Adverse Impact of COVID-19 on MSMEs in Indonesia. International Conference of Zakat, October, 203-218.

Sri Yayu Ninglasari, Mumuh Muhammad. (2021). Zakat Digitalization: Effectiveness of Zakat Management during Covid-19 Pandemic. Journal of Islamic Economic LawsJanuary, Vol. 4, No. 1.

Tarsi (2014). "Wakaf uang dengan sistem online", available at: www.pta-medan.go.id/. Diakses 1 November 2021.

Udo, G., Bagchi, K., Maity, M., 2016. Menggali faktor-faktor yang mempengaruhi pembajakan digital menggunakan aktivasi Norma dan model UTAUT: peran budaya nasional. J. Bis. Etika 135 (3), 517- 541.

Venkatesh, V., Thong, J. Y., \& Xu, X. (2012). Consumer Acceptance and Use of Information Technology: Extending the Unified Theory of Acceptance and Use of Technology. MIS Quaterly, vol. 36, no. 1, pp. 157-178.

Wirdiyanti, R. (2018), "Digital banking technology adoption and bank efficiency: the Indonesian case". Ojk, pp. 1-34.

Yang, S., Lu, Y., Gupta, S., Cao, Y., \& Zhang, R. (2012). Mobile payment services adoption across time: An empirical study of the effects of behavioral beliefs, social influences, and personal traits. Computers.

Zainab, AM, Kiran, K., Karim, NHA, \& Sukmawati, M. (2018). UTAUT konsistensi kinerja: Bukti empiris dari sistem manajemen perpustakaan.Jurnal Ilmu Perpustakaan \& Informasi Malaysia, 23(1), 17-32. 